\title{
Identification of Metabolism-Associated Biomarkers for Early and Precise Diagnosis of Oral Squamous Cell Carcinoma
}

\author{
Yuhan Wang ${ }^{1,+}$, Xiaoxin Zhang ${ }^{1,+}$, Shuai Wang ${ }^{1}$, Zihui Li ${ }^{1}$, Xinyang Hu ${ }^{1}$, Xihu Yang ${ }^{2}$, Yuxian Song ${ }^{1}$, Yue Jing ${ }^{1}$, \\ Qingang $\mathrm{Hu}^{3, *}$ and Yanhong $\mathrm{Ni}^{1, *}$
}

1 Central Laboratory of Stomatology, Nanjing Stomatological Hospital, Medical School of Nanjing University, Nanjing 210008, China; dg20350111@smail.nju.edu.cn (Y.W.); sissi.117@hotmail.com (X.Z.); ws0826@outlook.com (S.W.); mf21350182@smail.nju.edu.cn (Z.L.); mf21350178@smail.nju.edu.cn (X.H.); songyuxian1986@126.com (Y.S.); jingyueshadow@126.com (Y.J.)

2 Department of Oral and Maxillofacial Surgery, Affiliated Hospital of Jiangsu University, Zhenjiang 210008, China; yangxihu1981@126.com

3 Department of Oral and Maxillofacial Surgery, Nanjing Stomatological Hospital, Medical School of Nanjing University, Nanjing 210008, China

* Correspondence: qghu@nju.edu.cn (Q.H.); yanhong.ni@nju.edu.cn (Y.N.)

+ These authors contributed equally to this work.

check for updates

Citation: Wang, Y.; Zhang, X.; Wang, S.; Li, Z.; Hu, X.; Yang, X.; Song, Y.; Jing, Y.; Hu, Q.; Ni, Y. Identification of Metabolism-Associated Biomarkers for Early and Precise Diagnosis of Oral Squamous Cell Carcinoma. Biomolecules 2022, 12, 400. https://doi.org/10.3390/ biom 12030400

Academic Editors: Camile S. Farah and Antonio Celentano

Received: 9 January 2022 Accepted: 23 February 2022 Published: 4 March 2022

Publisher's Note: MDPI stays neutral with regard to jurisdictional claims in published maps and institutional affiliations.

Copyright: (C) 2022 by the authors. Licensee MDPI, Basel, Switzerland. This article is an open access article distributed under the terms and conditions of the Creative Commons Attribution (CC BY) license (https:// creativecommons.org/licenses/by/ $4.0 /)$.

\begin{abstract}
The 5-year survival rate for oral squamous cell carcinoma (OSCC), one of the most common head and neck cancers, has not improved in the last 20 years. Poor prognosis of OSCC is the result of failure in early and precise diagnosis. Metabolic reprogramming, including the alteration of the uptake and utilisation of glucose, amino acids and lipids, is an important feature of OSCC and can be used to identify its biomarkers for early and precise diagnosis. In this review, we summarise how recent findings of rewired metabolic networks in OSCC have facilitated early and precise diagnosis of OSCC.
\end{abstract}

Keywords: oral squamous cell carcinoma; metabolic reprogramming; biomarker; early diagnosis; precise diagnosis

\section{Introduction}

Oral squamous cell carcinoma (OSCC) is the most common head and neck malignancy, and its incidence has been increasing in several countries [1]. Treatment is mainly based on surgery, with radiotherapy and/or chemotherapy as adjuncts. Frustratingly, treatments have not significantly prolonged the survival of such patients [2,3], and the 5-year survival rate has remained at approximately $60 \%$ for the last 20 years [4]. The poor prognosis of OSCC patients is partly because of delayed diagnosis. Early screening and timely therapeutic intervention can effectively arrest OSCC progression, thereby increasing patient survival by $80 \%[5,6]$. OSCC diagnosis relies on clinician examination. However, some symptoms of OSCC appear similar to those of oral ulcers or precancerous lesions, leading to confusion. This phenomenon suggests that early screening for OSCC requires extensive experience. The gold standard for definitive diagnosis of OSCC is pathological diagnosis, which is invasive and leads to pain and poor wound healing [7]. In addition to the cumbersome histopathology procedures, sampling at different sites may result in different pathological diagnoses, and the complex procedures of pathological diagnosis cause a certain lag in obtaining clinical results $[8,9]$. Therefore, in clinical practice, there is an urgent demand for diagnostic tools with high specificity, manipulability and non-invasive or minimally invasive techniques to assist clinicians in OSCC screening. Once patients are suspected of having OSCC, a precise diagnosis that assists surgeons in planning surgery and predicting patient therapy responses is urgently required. For example, the difficulty in determining a 'clear' surgical margin is an important factor that influences the prognosis 
of OSCC. We previously reported that OSCC patients with mild dysplasia margins had a worse prognosis than those with negative margins [10]. Moreover, excess resection seriously affects the quality of life of patients. Hence, only a precise diagnosis can help characterise every patient based on molecular signatures and provide personalised treatments with predictable outcomes.

Metabolic rewiring is one of the six hallmarks of cancer, manifesting mainly as alterations in glucose, lipid and amino acid metabolism. Tumour cells experience complex stresses, including hypoxia, energy deprivation and an acidic environment, and must adapt to environmental pressures through metabolic reprogramming, which can be used to design metabolism-targeted diagnostic tools. For example, positron emission tomography, which records energy utilisation, is recommended for patients with head and neck cancer at clinical stages III and IV, and exhibits diagnostic advantages for detecting lymph node and distant metastasis [11]. Metabolic features vary across tumours of different tissue origins, genetic backgrounds and stages of the disease. Therefore, nuclear magnetic resonance (NMR) spectroscopy, mass spectrometry (MS), ambient ionisation MS and conductive polymer spray ionisation MS (CPSI-MS) have been performed to compare the metabolic variation among OSCC patients with different clinical stages and genetic backgrounds of the disease to identify novel metabolic landscapes of OSCC. Using these findings, early and precise diagnosis of OSCC should soon be realised.

In the last few years, many promising, innovative diagnostic techniques, such as narrow-band imaging, high-frequency ultrasounds, optical coherence tomography and in vivo confocal microscopy, have been applied as adjunctive non-invasive techniques to help diagnose OSCC [12]. Owing to detailed studies on metabolic pathways and tremendous advancements in techniques, the application of metabolite-targeted diagnosis in clinical settings has drawn great attention and shows promise. In this review, we analyse 93 papers and present an overview of how OSCC induces metabolic changes to adapt to a nutrient-poor environment and confer growth advantages to tumour cells. Unlike other reviews that focus on the metabolic characteristics of OSCC [13,14], this review classifies the identified metabolites according to sample types and their diagnostic values and discusses how these metabolites can be potentially applied for early and precise OSCC diagnosis.

\section{Altered Cellular Metabolism in OSCC}

\subsection{Glucose Metabolism}

\subsubsection{Glycolysis}

One of the earliest findings in cancer metabolic reprogramming was that tumour cells prefer glycolysis even in the presence of adequate oxygen. Glycolysis addiction in OSCC is evidenced by enhanced glucose uptake, which is mainly reflected by the upregulation of glucose transporter protein (GLUT) [15]. Higher GLUT1 and GLUT3 expression correlates with poor prognosis in OSCC patients [16-21]. In addition, when glucose is transported into the cytoplasm, it is catalysed by many glycolytic enzymes, among which hexokinase 2 (HK2), pyruvate kinase M2 (PKM2), phosphofructokinase (PFK) and glucose-6-phosphate dehydrogenase (G6PD) have also been shown to be upregulated in OSCC and associated with OSCC patient prognosis [22-26] (Figure 1). These results demonstrate that OSCC is characterised by enhanced glycolysis activity.

Enhanced glycolysis is accompanied by increased lactate production. LDH, which converts pyruvate to lactate, has been monitored in serum and saliva to detect and diagnose OSCC [27-30] (Figure 1). Analysis of LDH expression in tumour tissues can also be used to predict patient prognosis and chemotherapy responses [31-33]. Notably, abundant lactate in OSCC is produced not only by malignant cells but also by other cells in the tumour microenvironment, such as CAF. Lactate in the tumour microenvironment can be employed by tumour cells as a nutrient to promote cell proliferation and invasion [34-37]. Lactate is also a signalling metabolite, which lactylates histones to regulate gene expression [38]. The high levels and multiple functions of lactate in OSCC suggest that it is a promising glycolytic metabolite for OSCC detection and diagnosis. 


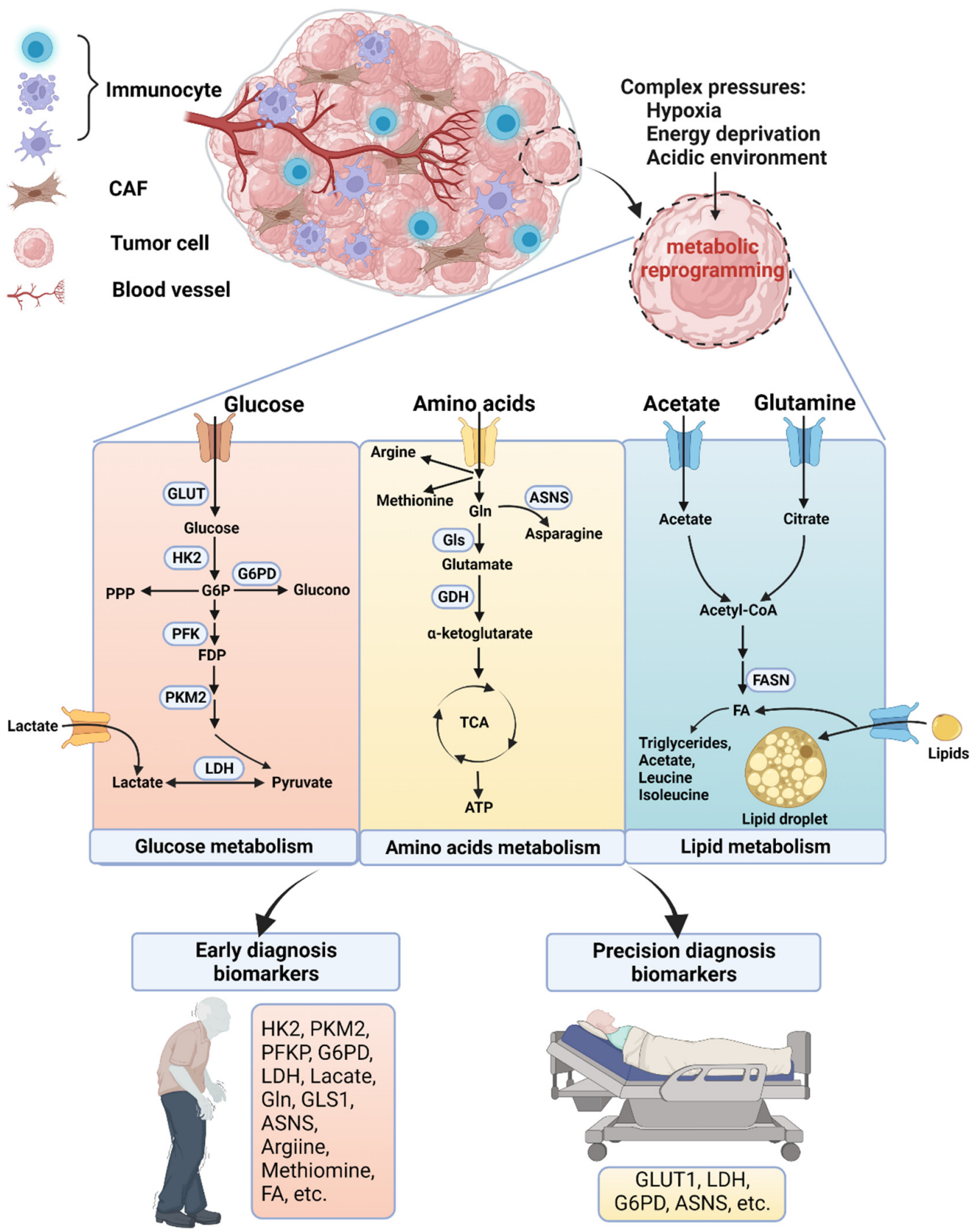

Figure 1. Screening altered cellular metabolism to diagnose OSCC. OSCC undergoes metabolic reprogramming of glucose, lipids and amino acids in response to complex pressures. Identifying metabolism-associated biomarkers facilitates early and precision diagnosis. CAF, cancer-associated fibroblast; LDH, lactate dehydrogenase; Gln, glutamine; ASNS, asparagine synthetase; Gls, glutaminase; GDH, glutamate dehydrogenase; TCA, tricarboxylic acid; ATP, adenosine triphosphate; FA, fatty acid; FASN, fatty acid synthase. Figure created with biorender.com.

\subsubsection{Pentose Phosphate Pathway (PPP)}

When glucose enters the cytoplasm and is phosphorylated by HK to glucose-6phosphate, it enters the PPP in addition to glycolysis (Figure 1). PPP contributes to OSCC progression by maintaining intracellular redox homeostasis, FA synthesis, and the production of ribose 5-phosphate for RNA and DNA synthesis [39]. The rate-limiting enzyme of PPP, G6PD, is regulated by NRF2 and associated with poor prognosis of OSCC [25], hence, G6PD-targeting limits cancer growth and metastasis by increasing reactive oxygen species (ROS) levels and endoplasmic reticulum stress $[40,41]$. Although few studies have further confirmed that PPP is enhanced in OSCC, three independent studies have demonstrated 
that transketolase (another PPP enzyme) is overexpressed in head and neck squamous cell carcinoma (HNSCC) cell lines and tissues [42-44]. Additionally, radiosensitive HNSCC cells display higher PPP activity than radioresistant cells [45]. Therefore, further research is required to confirm enhanced PPP activity in OSCC and to identify the key metabolites.

\subsection{Amino Acid Metabolism-Gln and Methionine}

It is now widely appreciated that tumour cells are characterised by not only dysregulated glucose metabolism but also enhanced requirements for amino acids [46]. Normal cells cannot synthesise essential amino acids (histidine, isoleucine, leucine, lysine, methionine, phenylalanine, threonine, tryptophan and valine) and obtain them exogenously. In contrast, tumour cells have an increased dependence on exogenous non-essential amino acids and display enhanced activity of amino acid synthesis, breakdown, and transport because amino acids can provide energy, regulate redox balance, and support protein and lipid synthesis [47].

Gln, the second primary nutrient for tumours, is a non-essential amino acid that is most abundant in circulation. Some tumour cells, including neuroblastoma [48], clear cell renal cell carcinoma [49], and breast cancer [50] cells, are addicted to Gln; hence, Gln depletion undermines their cell proliferation. As tumours consume more Gln than that required for biosynthesis, it must be transported from outside by Gln transporters. Fourteen amino acid transporters are responsible for the influx/efflux of Gln into/out of cells [51]. Among these transporters, ASCT2 (SLC1A5) exhibits higher affinity for Gln and is upregulated in OSCC [52,53]. Luo et al. found that depleting Gln by inhibiting ASCT2 impairs OSCC proliferation and tumour growth; this indicates the importance of Gln in OSCC [53].

Gln plays multiple roles in OSCC progression (Figure 1). Firstly, Gln replenishes the TCA cycle via $\alpha$-ketoglutarate $(\alpha-K G)$ to synthesise citrate and FA. Specifically, Gln is catalysed by Gls to glutamate, which is then converted to $\alpha-K G$ by GDH. Multiple research teams have confirmed that Gls is highly expressed in OSCC and that its expression correlates with poor prognosis in OSCC patients [54-56]. Moreover, Gls regulates the radiosensitivity of HNSCC cells $[57,58]$. Chang et al. found that the use of Gln by p53regulated Gls confers ROS resistance onto tumour cells [57]. GLUD expression in OSCC has not been observed. Only Cetindis et al. found weak expression of GLUD in OSCC [52], suggesting that Gln in OSCC may not participate in the TCA cycle to generate ATP. Secondly, Gln serves as a nitrogen donor to generate nucleotides and non-essential amino acids. Glutamate can be converted to asparagine by ASNS (Figure 1). Our group found that higher ASNS expression in OSCC positively correlated with lymph node metastasis and perineural invasion [59]. This implies that ASNS has the potential to be a significant factor for predicting the prognosis of OSCC patients. In addition, glutamate is a precursor of glutathione, which exerts antioxidant effects. Moreover, Gln contributes to the import of some essential amino acids. Furthermore, mitochondrial Gln is a precursor of 2-hydroxyglutarate, which increases stem cell marker expression [60].

Methionine, a methyl donor, contributes to the initiation and progression of OSCC via epigenetic modifications. Methionine adenosyltransferase generates S-adenosyl methionine using methionine as a substrate. DNA methyltransferases and histone methyltransferases then transfer a methyl group to cytosine or histones, respectively, to activate or repress gene expression. Owing to its importance, C-11-methionine positron emission tomography positron emission tomography (MET-PET) is clinically applied for some tumours to assist in diagnosis. Chowdhury et al. compared fluorodeoxyglucose-PET (FDG-PET) and METPET for oral cancer and showed that the uptake values of methionine and glucose are similar. Both uptakes increase in patients at a higher clinical stage [61]. More notably, Saleha et al. found that D-methionine protected normal oral tissue from radiation-induced cell death [62]. Therefore, MET-PET can be further applied to assess patient responses to radio therapy.

In addition to the aforementioned amino acids, OSCC may also rely on other amino acids, such as arginine $[63,64]$. All these studies confirmed that compared with normal 
cells, OSCC cells have different amino acid preferences and utilisation rates. Therefore, the levels of amino acids and their metabolising enzymes are promising diagnostic values; these are discussed below.

\subsection{Lipid Metabolism}

Lipid is a general term for various organic compounds, including glycerolipids, glycerophospholipids, sphingolipids and cholesterol [65]. Lipids are an outstanding medium for energy storage $[66,67]$ and are essential components of biological membranes $[68,69]$. They also transmit signals as vehicles [70], act as activators [71], or enzyme carriers involved in signal recognition, and participate in immunity responses [72]. A wide variety of lipids with diverse functions have constructed a massive, flexible network to fulfil the requirements of malignant cells.

Multiple studies have shown that the genes related to lipid metabolism are dysregulated in OSCC and that some of them are associated with patient prognosis and clinical features. Hu et al. found that obesity is an independent risk factor for early OSCC and that three genes responsible for lipid metabolism are predictors of prognosis [73]. Similarly, Gao et al. identified a 24-gene set related to lipid metabolism that could be used to predict OSCC prognosis, assist in diagnosis and choose rational treatments [74]. In addition, lipid metabolism-related proteins are differentially expressed in OSCC with variable differentiation [75]. All these results prove that lipid metabolism is dysregulated in OSCC.

FA uptake and synthesis are active in cancer cells. FA uptake is aided by low-density lipoprotein receptor, CD36, FA transporter proteins and FA binding proteins (Figure 1). CD36 in OSCC has been extensively studied and found to correlate with OSCC proliferation, migration and lymph-node metastasis [76-78]. Downregulating CD36 expression inhibits OSCC progression [77,79]. In addition, fatty-acid-binding protein 5 promotes OSCC migration [80]. Endogenous FA are synthesised from acetyl-CoA, which is then converted to malonyl-CoA by acetyl-CoA carboxylases. FASN then elongates acetyl-CoA to yield palmitate. FASN is upregulated in OSCC, and higher FASN expression in OSCC is associated with advanced disease and poor prognosis [81-83]. FASN not only promotes OSCC proliferation and migration but also enhances cell resistance to chemotherapy [84-86]. The de novo synthesised FA further connect via different backbones to form various lipids. For example, phospholipids consist of two FA, a glycerol unit and a phosphate group which is esterified to an organic molecule such as choline, glycerol or inositol. Hilvo et al. showed that de novo synthesised FA are incorporated into membrane phospholipids of breast cancer cells, and hence have diagnostic value [87].

Cholesterol also plays essential roles in tumorigenesis and cancer progression by forming membranes, modulating signals, and contributing to bile acid and steroid hormone synthesis. Cholesterol metabolism is altered in OSCC, and high cholesterol levels promote oral carcinogenesis $[88,89]$. Shutting down cholesterol efflux by silencing apolipoprotein E expression impairs OSCC invasion [90]. Multiple studies have shown that cholesterol synthesis is important for cancer cells. However, the function of cholesterol synthesis in OSCC remains undiscovered.

Saliva prostaglandin $E_{2}$ (PGE2) is another potential marker for OSCC diagnosis [91]. $\mathrm{Li}$ et al. found that PGE2 promotes OSCC proliferation. In addition to the direct detection of PGE2, cyclooxygenase (COX)-2, which is responsible for PGE2 production, has also been widely studied [92]. COX-2 expression is elevated in OSCC [93]. COX-2 promotes OSCC invasion and proliferation, which is partially dependent on PGE2 [94].

Owing to the close correlation between reprogrammed lipid metabolism and tumour progression, lipid metabolism enzymes and lipodomics have diagnostic potential. Although numerous studies have been conducted to identify markers for tumour diagnosis, no reliable markers have been found, and few are currently applied in clinical settings. The difficulty lies in technology insensitivity and various confounders (including patient fasting status and metabolic medications) [95]. However, owing to great advances in tech- 
nology and a more detailed stratification of patients, reliable markers will be identified in the future.

\section{Clinical Applications of Metabolism-Targeted Diagnosis}

Since OSCC metabolic reprogramming is recognised and altered metabolites have many effects on OSCC cell phenotypes, OSCC can potentially be screened by detecting changes in metabolites to determine disease malignancy and formulate appropriate treatment plans. The association between metabolites in liquid samples (saliva, serum and urine) of patients with OSCC or premalignant lesions and healthy individuals is one research focus. The correlation between metabolite levels in tumour tissues and clinical characteristics or prognosis has also been extensively studied. Herein, we summarise the recent developments.

\subsection{Metabolism-Targeted Early Diagnosis}

The main reason for delayed diagnosis of OSCC is the difficulty in distinguishing OSCC from other oral premalignant lesions using accurate non-invasive or minimally invasive strategies that are equivalent to histological diagnosis. Therefore, researchers have compared metabolites in easily collectible fluids from patients with OSCC or premalignant lesions and normal individuals to identify typical OSCC metabolites to assist physicians in diagnosis.

\subsubsection{Metabolism-Targeted Early Diagnosis-Saliva}

Saliva, which is readily available and can be non-invasively obtained, is the ideal choice of sample for OSCC diagnosis. Saliva is a mixture of water (93-94\%), organic and inorganic substances $(0.2 \%)$, proteins, and numerous cellular elements $(0.3 \%)$ which is produced by salivary glands located throughout the oral mucosa. In addition to the aforementioned molecules, saliva contains gingival crevicular fluid, serum transudate, epithelial cells, leukocytes, and many microorganisms. The various contents of saliva maintain oral homeostasis via lubrication, buffering, taste, digestion, and antibacterial, antiviral, and antifungal protection [96]. Individuals with different physiological and pathological conditions produce different saliva [97]. Therefore, many studies have attempted to compare saliva from patients with OSCC and normal individuals. Recently, capillary electrophoresis time-of-flight MS (CE-TOF-MS), gas chromatography coupled with MS (GC-MS), and ultraperformance liquid chromatography-MS (UPLC-MS) were used to profile metabolites in saliva, and several typical metabolites, including glycolysis metabolites, amino acids and lipids, were identified [98-101] (Table 1). We further analysed the most differential metabolites among these studies and found that five metabolites - taurine, valine, choline, cadaverine and tryptophan-had been simultaneously identified using three independent detection methods, indicating their application potential [99-101]. Notably, all these metabolites were hydrophilic because of the limitations of a single chromatographic method. To overcome this shortcoming, Wang et al. developed an integrated separation approach using reversedphase liquid chromatography and hydrophilic interaction chromatography combined with TOF-MS, and identified five potential markers (propionylcholine, $N$-acetyl-L-phenylalanine, sphinganine, phytosphingosine and S-carboxymethyl-L-cysteine) [102].

Early diagnosis of OSCC requires rapid equipment feedback. However, metabolic analysis of saliva using these types of equipment is time-consuming. Therefore, our group introduced an ambient-ionisation-based multiplex molecular screening method called CPSI-MS. The analysis time was reduced to a few seconds from the few weeks or months required when using traditional methods [103]. We showed that the diagnostic accuracy could reach $86.7 \%$ upon combining CPSI-MS with machine learning. 
Table 1. Metabolites in OSCC.

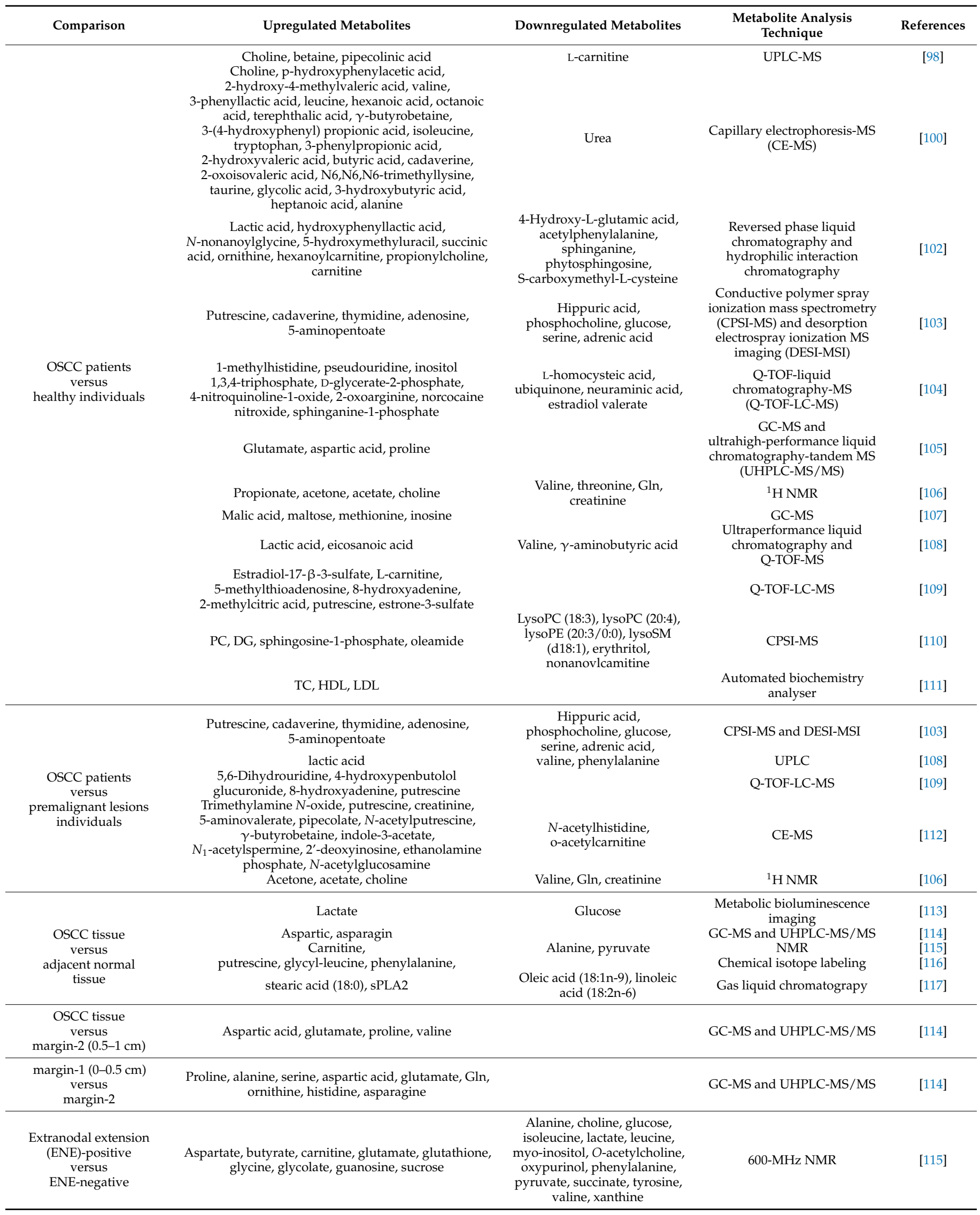


In addition, studies have been conducted to compare metabolites in tumours and premalignant lesions. Shigeo et al. found that 14 metabolites were significantly different in OSCC and oral lichen planus groups [112], confirming that saliva metabolites in oral leukoplakia and OSCC differed significantly (Table 1). They compared saliva samples using CE-MS and identified a panel of indole-3-acetate and ethanolamine phosphate to discriminate OSCC from oral lichen planus [112]. Similarly, Wei et al. used UPLC and identified a panel of valine, lactic acid and phenylalanine to distinguish OSCC from oral leukoplakia [108].

\subsubsection{Metabolism-Targeted Early Diagnosis-Serum and Urine}

In addition to saliva, serum and urine have been studied using metabolomics for early OSCC diagnosis. Q-TOF-LC-MS, GC-MS and ${ }^{1} \mathrm{H}$ NMR have been applied to discriminate OSCC from normal or oral leukoplakia $[109,118]$. However, we found that the number of patients in some of the aforementioned studies was small, which may have led to poor generalisability and stability of the results. This indicates that increasing the amount of patient data is necessary for validation. Therefore, we further compared the metabolites of serum from healthy individuals and 578 patients with OSCC using CPSI-MS [110]. Sixty-five metabolites were identified as potential markers. The accuracy of distinguishing individuals with OSCC from normal individuals was $98 \%$ in the discovery cohort and $89.6 \%$ in the validation cohort. This study is the largest metabolic study on serum for early OSCC diagnosis to date.

\subsection{Metabolism-Targeted Precision Diagnosis}

In addition to early diagnosis, a precise diagnosis to guide surgeons in operating and formulating treatment strategies is indispensable for improving OSCC prognosis and quality of life of patients. Some equipment targeting altered metabolism has been applied to precision diagnosis. For example, FDG-PET is recommended for patients with HNSCC. This technique displayed high sensitivity and accuracy for screening distant metastases and altered the management of $13.7 \%$ of patients [119-121]. In the following subsections, we summarise recent findings in metabolism-targeted precision diagnosis.

\subsubsection{Metabolism-Targeted Precision Diagnosis-Body Fluids}

Fluids, including saliva, serum and urine, are not only assayed to discriminate patients with OSCC from healthy individuals or individuals with oral premalignant lesions but also have precise diagnostic values. Since some metabolites in fluids reflect reprogrammed tumour metabolism, they are associated with clinical characteristics or histopathological grades. For example, glycolysis-related metabolites (pyruvate and lactate) in serum correlate with patients with OSCC at higher clinical stages or of more advanced histopathological grades [122]. Abnormal metabolic amino acid levels can also be used to determine OSCC prognosis. Notably, $600 \mathrm{MHz}$ NMR has been used to successfully analyse amino acid metabolomics in plasma, and a panel of amino acids to determine lymph node metastasis has been found [115]. Similarly, serum lipid levels, including those of cholesterol, highdensity lipoprotein and low-density lipoprotein, have been reported to gradually decrease with the development and progression of OSCC [111].

In addition to being indicators of clinical characteristics, metabolites in fluids have also been used to predict recurrence and therapy efficacy. Zuo et al. used UPLC-quadrupole/Orbitrap high-resolution MS to compare OSCC metabolites before and after operation and found that OSCC was less likely to recur in patients with low succinic acid and high hypoxanthine levels [123]. Furthermore, Ye et al. found that the metabolites related to glycolysis, redox homeostasis and anabolic progress could be used to predict chemotherapy efficacy with an accuracy of $100 \%, 81.25 \%$ and $100.0 \%$ in the training, test and external validation sets, respectively [124].

\subsubsection{Metabolism-Targeted Precision Diagnosis-Tissue Specimens}

Instead of measuring metabolites in fluids to indirectly reflect the characteristics of OSCC, many studies have focused on metabolic variations in tumour tissue. Traditional 
pathological diagnosis has proven that many metabolic-related enzymes are associated with patient prognosis and therapy sensitivity. However, these enzyme-dependent tests are not sufficient to accurately describe the metabolic signatures of OSCC. Therefore, researchers have detected metabolites in tissue specimens. Their findings show that the metabolites in tumours are associated with tumour invasion, neuropathic pain, and lymph-node metastasis [116,119,125]. Metabolic shifts have diagnostic value, similar to metabolite levels. Mignion analysed the relationship between lactate and pyruvate levels by adding isotopic markers to metabolites and created pyruvate-lactate dynamic metabolic images, which correlated with epidermal growth factor receptor inhibitor resistance in HNSCC [126].

In comparison with those in adjacent normal tissue, metabolites change in OSCC [14,113-116,127]. However, the metabolic trends in normal tissue and tumours were unknown until a study was conducted by Young et al., wherein the metabolic perturbation of distance-related surgical margins was analysed and four and six amino acids were identified as negative margin and dysplastic margin markers, respectively [114]. This work was particularly important as they tried to identify a panel of metabolites at the junction of normal and tumour tissues to determine the safe surgical margin. Using a reliable panel of identified metabolites, rapid evaporative ionisation MS (REIMS), which captures the gaseous ions generated during the cutting of cancer tissue with an electric knife and constructs a metabolomic profile of the corresponding tissue, will be translated from the laboratory bench to clinical application [128]. In addition, acquiring a vivid metabolic image of OSCC is also useful for surgeons, especially during surgery. Uchiyama et al. distinguished the cancer and stromal regions of OSCC using imaging MS [129]. Young et al. further applied DESI-MS imaging and developed 14 lipid ion molecular diagnostic models to measure safe surgical resection distances for OSCC [130]. This attempt was successful in using OSCC lipid metabolomics to guide the surgical treatment of OSCC and identify small tumour foci at the surgical margin. It may be possible to determine the 'cleanliness' of surgical margins in real-time by surgical margin metabolite detection in the operating room to eliminate the hidden danger of residual tumour foci. Currently, the assessment of surgical safety margins using DESI-MS for gastric [131], prostate [132] and breast cancers [133] is highly compatible with the pathological results. We believe that the clinical application of REIMS and DESI-MS during surgery has the potential to make individualised surgical safety margins possible.

\section{Future Research Directions of Metabolomics Applied to OSCC Diagnosis}

From the perspective of clinical needs, the use of molecular markers to identify signs of progression of oral premalignant lesions to OSCC in a timely manner, or to accurately screen OSCC patients at the time of initial diagnosis, can effectively halt OSCC progression. For patients with a clear diagnosis of OSCC, identifying small tumour foci that remain at the surgical margins, or predicting therapy responses, will improve the quality of life and prolong survival (Figure 2). The current screening tools, which are primarily based on imaging to discriminate OSCC, have shortcomings. High false-positive and false-negative rates limit their clinical application. In addition, the lack of objective evaluation data also limits their development. OSCC patients undergo significant metabolic reprogramming. The identification of differential metabolites through easily accessible fluids with non-invasive or minimally invasive tools will provide a new avenue for the evaluation of OSCC as an adjunctive diagnostic technique. Although great progress has been made in metabolitetargeted OSCC diagnosis, there is still a long way to go. Based on this review, we suggest that researchers (1) develop standardised sample collection procedures; (2) focus on OSCC patient-specific metabolites, especially differential metabolites in OSCC and pre-cancerous lesions; (3) explore the association between metabolite signatures and clinical characteristics or prognosis to develop metabolic grading criteria; (4) develop economical, rapid and technologically insensitive metabolomics tools; and (5) use a combination of multidisciplinary tools, such as AI, optical coherence tomography and immune cell infiltration analysis. 
A Identification of metabolism-associated biomarkers for early and precise diagnosis of OSCC
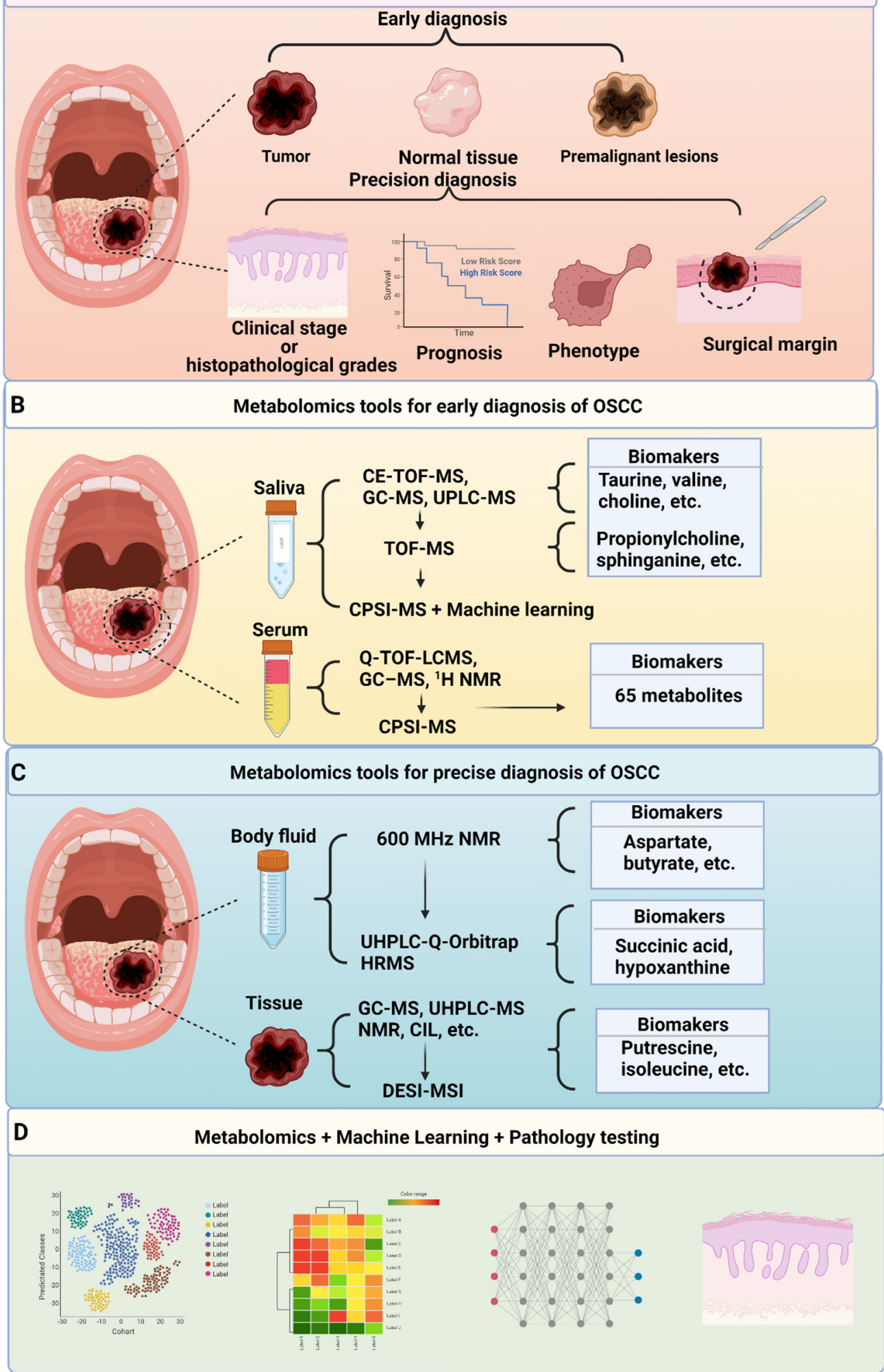

Figure 2. Clinical application of metabolomics to OSCC diagnosis. (A). Screening for metabolismassociated biomarkers to assist in early and precise diagnosis of OSCC; $(\mathbf{B}, \mathbf{C})$. With the advancement of metabolomics tools, some metabolism-associated biomarkers for early and precise diagnosis of OSCC have been screened by testing saliva, serum, body fluid and tissue samples; (D). Constructing a diagnostic model combined metabolomics with machine learning and pathology testing is valuable. Figure created with biorender.com. 


\section{Conclusions}

Since OSCC induces significant metabolic reprogramming, screening for differential metabolites may assist in the diagnosis of this disease. Progress has been made in metabolomic diagnosis of OSCC; however, many problems remain unsolved. Further validation and optimisation of known metabolic diagnostic markers are necessary, and hence there is still a lot to be done.

Author Contributions: Conceptualization, Q.H. and Y.N.; investigation, Y.W., Z.L., X.H. and S.W.; data curation, Y.W., X.Z. and S.W.; writing-original draft preparation, Y.W., X.Y. and X.Z.; writingreview and editing, Y.S. and Y.J.; visualization, Y.W. All authors have read and agreed to the published version of the manuscript.

Funding: This research was funded by National Natural Science Foundation of China (No. 82173159, 82002865 , 82173380, 81902759), the Key Research and Development Projects in Jiangsu Province (No. BE2020628), and Nanjing Medical Science and Technique Development Foundation (No. ZKX18035, YKK19091, YKK20151 and QRX17083).

Institutional Review Board Statement: Not applicable.

Informed Consent Statement: Not applicable.

Conflicts of Interest: The authors declare no conflict of interest.

\section{References}

1. Du, M.; Nair, R.; Jamieson, L.; Liu, Z.; Bi, P. Incidence Trends of Lip, Oral Cavity, and Pharyngeal Cancers: Global Burden of Disease 1990-2017. J. Dent. Res. 2019, 99, 143-151. [CrossRef] [PubMed]

2. Koyfman, S.A.; Ismaila, N.; Crook, D.; D'Cruz, A.; Rodriguez, C.P.; Sher, D.J.; Silbermins, D.; Sturgis, E.M.; Tsue, T.T.; Weiss, J.; et al. Management of the Neck in Squamous Cell Carcinoma of the Oral Cavity and Oropharynx: ASCO Clinical Practice Guideline. J. Clin. Oncol. 2019, 37, 1753-1774. [CrossRef] [PubMed]

3. Machiels, J.-P.; Leemans, C.R.; Golusinski, W.; Grau, C.; Licitra, L.; Gregoire, V. Squamous cell carcinoma of the oral cavity, larynx, oropharynx and hypopharynx: EHNS-ESMO-ESTRO Clinical Practice Guidelines for diagnosis, treatment and follow-up. Ann. Oncol. 2020, 31, 1462-1475. [CrossRef]

4. Zanoni, D.K.; Montero, P.H.; Migliacci, J.C.; Shah, J.P.; Wong, R.J.; Ganly, I.; Patel, S.G. Survival outcomes after treatment of cancer of the oral cavity (1985-2015). Oral Oncol. 2019, 90, 115-121. [CrossRef] [PubMed]

5. Madhura, M.G.; Rao, R.S.; Patil, S.; Fageeh, H.N.; Alhazmi, A.; Awan, K.H. Advanced diagnostic aids for oral cancer Disease-a-Month 2020, 66, 101034. [CrossRef] [PubMed]

6. Silverman, S.; Kerr, A.R.; Epstein, J.B. Oral and Pharyngeal Cancer Control and Early Detection. J. Cancer Educ. 2010, $25,279-281$. [CrossRef] [PubMed]

7. Lajolo, C.; Gioco, G.; Rupe, C.; Patini, R.; Rizzo, I.; Romeo, U.; Contaldo, M.; Cordaro, M. Patient perception after oral biopsies: An observational outpatient study. Clin. Oral Investig. 2021, 25, 5687-5697. [CrossRef] [PubMed]

8. Steigen, S.E.; Søland, T.M.; Nginamau, E.S.; Laurvik, H.; Costea, D.; Johannessen, A.C.; Jebsen, P.; Bjerkli, I.; Uhlin-Hansen, L.; Hadler-Olsen, E. Grading of oral squamous cell carcinomas - Intra and interrater agreeability: Simpler is better? J. Oral Pathol. Med. 2020, 49, 630-635. [CrossRef] [PubMed]

9. Wick, M.R. The hematoxylin and eosin stain in anatomic pathology-An often-neglected focus of quality assurance in the laboratory. Semin. Diagn. Pathol. 2019, 36, 303-311. [CrossRef]

10. Pu, Y.; Wang, Y.; Huang, X.; Chen, S.; Wang, Z.; Sun, G.; Tang, E.; Zhao, S.; Ni, Y.; Hu, Q. The influence of mild dysplasia at the surgical margin on the prognosis of oral squamous cell carcinoma. Int. J. Oral Maxillofac. Surg. 2016, 45, 1372-1377. [CrossRef]

11. Zheng, E.; Khariwala, S.S. Do All Patients With Head and Neck Cancer Require a Positron Emission Tomography Scan at Diagnosis? Laryngoscope 2019, 129, 537-538. [CrossRef] [PubMed]

12. Romano, A.; Di Stasio, D.; Petruzzi, M.; Fiori, F.; Lajolo, C.; Santarelli, A.; Lucchese, A.; Serpico, R.; Contaldo, M. Noninvasive Imaging Methods to Improve the Diagnosis of Oral Carcinoma and Its Precursors: State of the Art and Proposal of a Three-Step Diagnostic Process. Cancers 2021, 13, 2864. [CrossRef] [PubMed]

13. Vitório, J.G.; Duarte-Andrade, F.F.; Pereira, T.D.S.F.; Fonseca, F.P.; Amorim, L.S.D.; Martins-Chaves, R.R.; Gomes, C.C.; Canuto, G.A.B.; Gomez, R.S. Metabolic landscape of oral squamous cell carcinoma. Metabolomics 2020, 16, 105. [CrossRef] [PubMed]

14. Chen, X.; Yu, D. Metabolomics study of oral cancers. Metabolomics 2019, 15, 22. [CrossRef]

15. Guttikonda, V.R.; Harshani, J.M.; Yeluri, S. Glut-1 as a prognostic biomarker in oral squamous cell carcinoma. J. Oral Maxillofac. Pathol. 2014, 18, 372-378. [CrossRef]

16. Ayala, F.R.R.; Rocha, R.M.; Carvalho, K.C.; Carvalho, A.; Da Cunha, I.W.; Lourenço, S.V.; Soares, F.A. Glut1 and Glut3 as Potential Prognostic Markers for Oral Squamous Cell Carcinoma. Molecules 2010, 15, 2374-2387. [CrossRef] 
17. Eckert, A.W.; Lautner, M.H.W.; Schütze, A.; Taubert, H.; Schubert, J.; Bilkenroth, U. Coexpression of hypoxia-inducible factor-1 $\alpha$ and glucose transporter-1 is associated with poor prognosis in oral squamous cell carcinoma patients. Histopathology 2011, 58, 1136-1147. [CrossRef] [PubMed]

18. Grimm, M.; Munz, A.; Teriete, P.; Nadtotschi, T.; Reinert, S. GLUT-1(+)/TKTL1(+) coexpression predicts poor outcome in oral squamous cell carcinoma. Oral Surg. Oral Med. Oral Pathol. Oral Radiol. 2014, 117, 743-753. [CrossRef] [PubMed]

19. Kunkel, M.; Moergel, M.; Stockinger, M.; Jeong, J.H.; Fritz, G.; Lehr, H.A.; Whiteside, T.L. Overexpression of GLUT-1 is associated with resistance to radiotherapy and adverse prognosis in squa-mous cell carcinoma of the oral cavity. Oral Oncol. 2007, 43, 796-803. [CrossRef]

20. Kunkel, M.; Reichert, T.E.; Benz, P.; Lehr, H.-A.; Jeong, J.-H.; Wieand, S.; Bartenstein, P.; Wagner, W.; Whiteside, T.L. Overexpression of Glut-1 and increased glucose metabolism in tumors are associated with a poor prognosis in patients with oral squamous cell carcinoma. Cancer 2003, 97, 1015-1024. [CrossRef]

21. Nakazato, K.; Mogushi, K.; Kayamori, K.; Tsuchiya, M.; Takahashi, K.; Sumino, J.; Michi, Y.; Yoda, T.; Uzawa, N. Glucose metabolism changes during the development and progression of oral tongue squamous cell carcinomas. Oncol. Lett. 2019, 18, 1372-1380. [CrossRef]

22. Kurihara-Shimomura, M.; Sasahira, T.; Nakashima, C.; Kuniyasu, H.; Shimomura, H.; Kirita, T. The Multifarious Functions of Pyruvate Kinase M2 in Oral Cancer Cells. Int. J. Mol. Sci. 2018, 19, 2907. [CrossRef]

23. Park, Y.J.; Kim, J.Y.; Lee, D.Y.; Zhang, X.; Bazarsad, S.; Chung, W.Y.; Kim, J. PKM2 enhances cancer invasion via ETS-1-dependent induction of matrix metalloproteinase in oral squa-mous cell carcinoma cells. PLoS ONE 2019, 14, e0216661.

24. Sun, X.; Zhang, L. MicroRNA-143 suppresses oral squamous cell carcinoma cell growth, invasion and glucose metabolism through targeting hexokinase 2. Biosci. Rep. 2017, 37, BSR20160404. [CrossRef] [PubMed]

25. Wang, Y.; Li, Q.; Niu, L.; Xu, L.; Guo, Y.; Wang, L.; Guo, C. Suppression of G6PD induces the expression and bisecting GlcNAcbranched N-glycosylation of E-Cadherin to block epithelial-mesenchymal transition and lymphatic metastasis. Br. J. Cancer 2020, 123, 1315-1325. [CrossRef] [PubMed]

26. Zhu, X.; Du, J.; Gu, Z. Circ-PVT1/miR-106a-5p/HK2 axis regulates cell growth, metastasis and glycolytic metabolism of oral squamous cell carcinoma. Mol. Cell. Biochem. 2020, 474, 147-158. [CrossRef] [PubMed]

27. Gholizadeh, N.; Ramandi, M.A.; Motiee-Langroudi, M.; Jafari, M.; Sharouny, H.; Sheykhbahaei, N. Serum and salivary levels of lactate dehydrogenase in oral squamous cell carcinoma, oral lichen planus and oral lichenoid reaction. BMC Oral Heal. 2020, 20, 1-8. [CrossRef] [PubMed]

28. Joshi, P.S.; Golgire, S. A study of salivary lactate dehydrogenase isoenzyme levels in patients with oral leukoplakia and squamous cell carcinoma by gel electrophoresis method. J. Oral Maxillofac. Pathol. 2014, 18, 39-44. [CrossRef] [PubMed]

29. Lokesh, K.; Kannabiran, J.; Rao, M.D. Salivary Lactate Dehydrogenase (LDH)—A Novel Technique in Oral Cancer Detection and Diagnosis. J. Clin. Diagn. Res. 2016, 10, ZC34-ZC37. [CrossRef]

30. Saluja, T.S.; Spadigam, A.; Dhupar, A.; Syed, S. Equating salivary lactate dehydrogenase (LDH) with LDH-5 expression in patients with oral squamous cell carcinoma: An insight into metabolic reprogramming of cancer cell as a predictor of aggressive phenotype. Tumor Biol. 2015, 37, 5609-5620. [CrossRef]

31. Cai, H.; Li, J.; Zhang, Y.; Liao, Y.; Zhu, Y.; Wang, C.; Hou, J. LDHA Promotes Oral Squamous Cell Carcinoma Progression Through Facilitating Glycolysis and Epitheli-al-Mesenchymal Transition. Front. Oncol. 2019, 9, 1446. [CrossRef] [PubMed]

32. Grimm, M.; Alexander, D.; Munz, A.; Hoffmann, J.; Reinert, S. Increased LDH5 expression is associated with lymph node metastasis and outcome in oral squamous cell carcinoma. Clin. Exp. Metastasis 2012, 30, 529-540. [CrossRef] [PubMed]

33. Sun, W.; Zhang, X.; Ding, X.; Li, H.; Geng, M.; Xie, Z.; Wu, H.; Huang, M. Lactate Dehydrogenase B Is Associated with the Response to Neoadjuvant Chemotherapy in Oral Squamous Cell Carcinoma. PLoS ONE 2015, 10, e0125976. [CrossRef] [PubMed]

34. Jiang, E.; Xu, Z.; Wang, M.; Yan, T.; Huang, C.; Zhou, X.; Liu, Q.; Wang, L.; Chen, Y.; Wang, H.; et al. Tumoral microvesicleactivated glycometabolic reprogramming in fibroblasts promotes the progression of oral squamous cell carcinoma. FASEB J. 2019, 33, 5690-5703. [CrossRef]

35. Zhang, Z.; Gao, Z.; Rajthala, S.; Sapkota, D.; Dongre, H.; Parajuli, H.; Suliman, S.; Das, R.; Li, L.; Bindoff, L.A.; et al. Metabolic reprogramming of normal oral fibroblasts correlated with increased glycolytic metabolism of oral squamous cell carcinoma and precedes their activation into carcinoma associated fibroblasts. Cell. Mol. Life Sci. 2020, 77, 1115-1133. [CrossRef]

36. Zhao, H.; Hu, C.-Y.; Chen, W.-M.; Huang, P. Lactate Promotes Cancer Stem-like Property of Oral Sequamous Cell Carcinoma. Curr. Med Sci. 2019, 39, 403-409. [CrossRef]

37. Zhao, H.; Jiang, E.; Shang, Z. 3D Co-culture of Cancer-Associated Fibroblast with Oral Cancer Organoids. J. Dent. Res. 2021, 100, 201-208. [CrossRef]

38. Zhang, D.; Tang, Z.; Huang, H.; Zhou, G.; Cui, C.; Weng, Y.; Liu, W.; Kim, S.; Lee, S.; Perez-Neut, M.; et al. Metabolic regulation of gene expression by histone lactylation. Nature 2019, 574, 575-580. [CrossRef]

39. Jiang, P.; Du, W.; Wu, M. Regulation of the pentose phosphate pathway in cancer. Protein Cell 2014, 5, 592-602. [CrossRef]

40. Mele, L.; Paino, F.; Papaccio, F.; Regad, T.; Boocock, D.; Stiuso, P.; Lombardi, A.; Liccardo, D.; Aquino, G.; Barbieri, A.; et al. A new inhibitor of glucose-6-phosphate dehydrogenase blocks pentose phosphate pathway and suppresses malignant proliferation and metastasis in vivo. Cell Death Dis. 2018, 9, 572. [CrossRef] 
41. Tang, Y.-C.; Hsiao, J.-R.; Jiang, S.-S.; Chang, J.-Y.; Chu, P.-Y.; Liu, K.-J.; Fang, H.-L.; Lin, L.-M.; Chen, H.-H.; Huang, Y.-W.; et al. c-MYC-directed NRF2 drives malignant progression of head and neck cancer via glucose-6-phosphate dehydrogenase and transketolase activation. Theranostics 2021, 11, 5232-5247. [CrossRef] [PubMed]

42. Smith, I.M.; Glazer, C.A.; Mithani, S.K.; Ochs, M.F.; Sun, W.; Bhan, S.; Vostrov, A.; Abdullaev, z.; Lobanenkov, V.; Gray, A.; et al. Coordinated activation of candidate proto-oncogenes and cancer testes antigens via promoter demethyla-tion in head and neck cancer and lung cancer. PLoS ONE 2009, 4, e4961. [CrossRef] [PubMed]

43. Sun, W.; Liu, Y.; Glazer, C.A.; Shao, C.; Bhan, S.; Demokan, S.; Zhao, M.; Rudek, M.A.; Ha, P.K.; Califano, J.A. TKTL1 Is Activated by Promoter Hypomethylation and Contributes to Head and Neck Squamous Cell Carcinoma Carcinogenesis through Increased Aerobic Glycolysis and HIF1 Stabilization. Clin. Cancer Res. 2010, 16, 857-866. [CrossRef] [PubMed]

44. Völker, H.-U.; Scheich, M.; Schmausser, B.; Kämmerer, U.; Eck, M. Overexpression of transketolase TKTL1 is associated with shorter survival in laryngeal squamous cell carcinomas. Eur. Arch. Otorhinolaryngol. 2007, 264, 1431-1436. [CrossRef]

45. Mims, J.; Bansal, N.; Bharadwaj, M.S.; Chen, X.; Molina, A.J.; Tsang, A.W.; Furdui, C.M. Energy Metabolism in a Matched Model of Radiation Resistance for Head and Neck Squamous Cell Cancer. Radiat. Res. 2015, 183, 291-304. [CrossRef] [PubMed]

46. Sivanand, S.M.; Vander Heiden, G. Emerging Roles for Branched-Chain Amino Acid Metabolism in Cancer. Cancer Cell 2020, 37, 147-156. [CrossRef] [PubMed]

47. Lieu, E.L.; Nguyen, T.; Rhyne, S.; Kim, J. Amino acids in cancer. Exp. Mol. Med. 2020, 52, 15-30. [CrossRef]

48. Valter, K.; Maximchik, P.; Abdrakhmanov, A.; Senichkin, V.; Zhivotovsky, B.; Gogvadze, V. Distinct effects of etoposide on glutamine-addicted neuroblastoma. Cell Mol. Life Sci. 2020, 77, 1197-1207. [CrossRef]

49. Fu, Q.; Xu, L.; Wang, Y.; Jiang, Q.; Liu, Z.; Zhang, J.; Zhou, Q.; Zeng, H.; Tong, S.; Wang, T.; et al. Tumor-associated Macrophagederived Interleukin-23 Interlinks Kidney Cancer Glutamine Addiction with Immune Evasion. Eur. Urol. 2019, 75, 752-763. [CrossRef]

50. Cluntun, A.A.; Lukey, M.J.; Cerione, R.A.; Locasale, J.W. Glutamine Metabolism in Cancer: Understanding the Heterogeneity. Trends Cancer 2017, 3, 169-180. [CrossRef] [PubMed]

51. El Ansari, R.; McIntyre, A.; Craze, M.L.; Ellis, I.; A Rakha, E.; Green, A.R. Altered glutamine metabolism in breast cancer; subtype dependencies and alternative adaptations. Histopathology 2017, 72, 183-190. [CrossRef] [PubMed]

52. Cetindis, M.; Biegner, T.; Munz, A.; Teriete, P.; Reinert, S.; Grimm, M. Glutaminolysis and carcinogenesis of oral squamous cell carcinoma. Eur. Arch. Otorhinolaryngol. 2015, 273, 495-503. [CrossRef] [PubMed]

53. Luo, Y.; Li, W.; Ling, Z.; Hu, Q.; Fan, Z.; Cheng, B.; Tao, X. ASCT2 overexpression is associated with poor survival of OSCC patients and ASCT2 knockdown inhibited growth of glutamine-addicted OSCC cells. Cancer Med. 2020, 9, 3489-3499. [CrossRef] [PubMed]

54. Yang, J.; Guo, Y.; Seo, W.; Zhang, R.; Lu, C.; Wang, Y.; Luo, L.; Paul, B.; Yan, W.; Saxena, D.; et al. Targeting cellular metabolism to reduce head and neck cancer growth. Sci. Rep. 2019, 9, 4995. [CrossRef]

55. Kamarajan, P.; Rajendiran, T.M.; Kinchen, J.; Bermúdez, M.; Danciu, T.; Kapila, Y.L. Head and Neck Squamous Cell Carcinoma Metabolism Draws on Glutaminolysis, and Stemness Is Specifically Regulated by Glutaminolysis via Aldehyde Dehydrogenase. J. Proteome Res. 2017, 16, 1315-1326. [CrossRef] [PubMed]

56. Wang, T.; Cai, B.; Ding, M.; Su, Z.; Liu, Y.; Shen, L. c-Myc Overexpression Promotes Oral Cancer Cell Proliferation and Migration by Enhancing Glutaminase and Glutamine Synthetase Activity. Am. J. Med. Sci. 2019, 358, 235-242. [CrossRef] [PubMed]

57. Chang, H.W.; Lee, M.; Lee, Y.S.; Kim, S.H.; Lee, J.C.; Park, J.J.; Nam, H.Y.; Kim, M.R.; Han, M.W.; Kim, S.W.; et al. p53-dependent glutamine usage determines susceptibility to oxidative stress in radioresistant head and neck cancer cells. Cell. Signal. 2020, 77, 109820. [CrossRef] [PubMed]

58. Wicker, C.A.; Hunt, B.G.; Krishnan, S.; Aziz, K.; Parajuli, S.; Palackdharry, S.; Elaban, W.R.; Wise-Draper, T.M.; Mills, G.B.; Waltz S.E.; et al. Glutaminase inhibition with telaglenastat (CB-839) improves treatment response in combination with ionizing radiation in head and neck squamous cell carcinoma models. Cancer Lett. 2021, 502, 180-188. [CrossRef] [PubMed]

59. Fu, Y.; Ding, L.; Yang, X.; Ding, Z.; Huang, X.; Zhang, L.; Chen, S.; Hu, Q.; Ni, Y. Asparagine Synthetase-Mediated l-Asparagine Metabolism Disorder Promotes the Perineural Invasion of Oral Squamous Cell Carcinoma. Front. Oncol. 2021, 11, 637226. [CrossRef]

60. Yoo, H.C.; Yu, Y.C.; Sung, Y.; Han, J.M. Glutamine reliance in cell metabolism. Exp. Mol. Med. 2020, 52, 1496-1516. [CrossRef]

61. Fatema, C.N.; Kuroshima, T.; Asaka, T.; Abe, T.; Sato, J.; Shiga, T.; Kuge, Y.; Tamaki, N.; Kitagawa, Y. Prognostic value of MET-PET in oral cancer. J. Nucl. Med. 2017, 58, 285.

62. Vuyyuri, S.B.; Hamstra, D.A.; Khanna, D.; Hamilton, C.A.; Markwart, S.M.; Campbell, K.C.; Sunkara, P.; Ross, B.D.; Rehemtulla, A. Evaluation of d-Methionine as a Novel Oral Radiation Protector for Prevention of Mucositis. Clin. Cancer Res. 2008, 14, 2161-2170. [CrossRef]

63. Huang, C.-C.; Tsai, S.-T.; Kuo, C.-C.; Chang, J.S.; Jin, Y.-T.; Chang, J.-Y.; Hsiao, J.-R. Arginine deprivation as a new treatment strategy for head and neck cancer. Oral Oncol. 2012, 48, 1227-1235. [CrossRef] [PubMed]

64. Leung, L.L.; Lau, N.C.H.; Liu, J.; Qu, X.; Tsui, S.K.-W.; Hou, J.; Law, C.T.-Y.; Ng, T.H.; Yam, J.W.P.; Chow, C.; et al. The Role of Arginine Metabolism in Oral Tongue Squamous Cell Carcinoma. Cancers 2021, 13, 6068. [CrossRef]

65. Fahy, E.; Subramaniam, S.; Murphy, R.C.; Nishijima, M.; Raetz, C.R.H.; Shimizu, T.; Spener, F.; van Meer, G.; Wakelam, M.; Dennis, E.A. Update of the LIPID MAPS comprehensive classification system for lipids. J. Lipid Res. 2009, 50, S9-S14. [CrossRef] 
66. Corbet, C.; Bastien, E.; Santiago de Jesus, J.P.; Dierge, E.; Martherus, R.; Vander Linden, C.; Doix, B.; Degavre, C.; Guilbaud, C.; Petit, L. TGFbeta2-induced formation of lipid droplets supports acidosis-driven EMT and the metastatic spreading of cancer cells. Nat. Commun. 2020, 11, 454. [CrossRef]

67. Li, P.; Lu, M.; Shi, J.; Gong, Z.; Hua, L.; Li, Q.; Lim, B.; Zhang, X.H.-F.; Chen, X.; Li, S.; et al. Lung mesenchymal cells elicit lipid storage in neutrophils that fuel breast cancer lung metastasis. Nat. Immunol. 2020, 21, 1444-1455. [CrossRef] [PubMed]

68. Harayama, T.; Riezman, H. Understanding the diversity of membrane lipid composition. Nat. Rev. Mol. Cell Biol. 2018, 19, 281-296. [CrossRef]

69. London, E. Membrane Structure-Function Insights from Asymmetric Lipid Vesicles. Accounts Chem. Res. 2019, 52, $2382-2391$. [CrossRef] [PubMed]

70. Wierbowski, B.M.; Petrov, K.; Aravena, L.; Gu, G.; Xu, Y.; Salic, A. Hedgehog Pathway Activation Requires Coreceptor-Catalyzed, Lipid-Dependent Relay of the Sonic Hedgehog Ligand. Dev. Cell 2020, 55, 450-467.e8. [CrossRef] [PubMed]

71. Borcik, C.G.; Versteeg, D.B.; Amani, R.; Yekefallah, M.; Khan, N.H.; Wylie, B.J. The Lipid Activation Mechanism of a Transmembrane Potassium Channel. J. Am. Chem. Soc. 2020, 142, 14102-14116. [CrossRef] [PubMed]

72. Simons, K.; Toomre, D. Lipid rafts and signal transduction. Nat. Rev. Mol. Cell Biol. 2000, 1, 31-39. [CrossRef] [PubMed]

73. Hu, Q.; Peng, J.; Chen, X.; Li, H.; Song, M.; Cheng, B.; Wu, T. Obesity and genes related to lipid metabolism predict poor survival in oral squamous cell carcinoma. Oral Oncol. 2019, 89, 14-22. [CrossRef]

74. Gao, J.; Tian, G.; Han, X.; Zhu, Q. Twenty-four signature genes predict the prognosis of oral squamous cell carcinoma with high accuracy and repeatability. Mol. Med. Rep. 2017, 17, 2982-2990. [CrossRef] [PubMed]

75. Mohanty, V.; Subbannayya, Y.; Patil, S.; Puttamallesh, V.N.; Najar, M.; Datta, K.K.; Pinto, S.M.; Begum, S.; Mohanty, N.; Routray, $\mathrm{S}$. Molecular alterations in oral cancer using high-throughput proteomic analysis of formalin-fixed paraf-fin-embedded tissue. J. Cell Commun. Signal. 2021, 15, 447-459. [CrossRef] [PubMed]

76. Haidari, S.; Tröltzsch, M.; Knösel, T.; Liokatis, P.; Kasintsova, A.; Eberl, M.; Ortner, F.; Otto, S.; Fegg, F.; Boskov, M.; et al. Fatty Acid Receptor CD36 Functions as a Surrogate Parameter for Lymph Node Metastasis in Oral Squa-mous Cell Carcinoma. Cancers 2021, 13, 4125. [CrossRef] [PubMed]

77. Chen, L.; Xia, J.S.; Wu, J.H.; Chen, Y.G.; Qiu, C.J. Quercetin suppresses cell survival and invasion in oral squamous cell carcinoma via the miR-1254/CD36 cascade in vitro. Hum. Exp. Toxicol. 2021, 40, 1413-1421. [CrossRef]

78. Sakurai, K.; Tomihara, K.; Yamazaki, M.; Heshiki, W.; Moniruzzaman, R.; Tachinami, H.; Ikeda, A.; Imaue, S.; Fujiwara, K. CD36 expression on oral squamous cell carcinoma cells correlates with enhanced proliferation and mi-gratory activity. Oral Dis. 2020, 26, 745-755. [CrossRef] [PubMed]

79. Chen, R.; Zhang, Y.; Zhang, X. MiR-1254 Functions as a Tumor Suppressor in Oral Squamous Cell Carcinoma by Targeting CD36. Technol. Cancer Res. Treat. 2019, 18, 1533033819859447. [CrossRef]

80. Fang, L.-Y.; Wong, T.-Y.; Chiang, W.-F.; Chen, Y.-L. Fatty-acid-binding protein 5 promotes cell proliferation and invasion in oral squamous cell carcinoma. J. Oral Pathol. Med. 2010, 39, 342-348. [CrossRef]

81. da Silva, S.D.; Cunha, I.W.; Nishimoto, I.N.; Soares, F.A.; Carraro, D.M.; Kowalski, L.P.; Graner, E. Clinicopathological significance of ubiquitin-specific protease 2a (USP2a), fatty acid synthase (FASN), and ErbB2 expression in oral squamous cell carcinomas. Oral Oncol. 2009, 45, e134-e139. [CrossRef]

82. Silva, S.D.; Cunha, I.W.; Rangel, A.L.C.A.; Jorge, J.; Zecchin, K.G.; Agostini, M.; Kowalski, L.P.; Coletta, R.D.; Graner, E. Differential expression of fatty acid synthase (FAS) and ErbB2 in nonmalignant and malignant oral keratinocytes. Virchows Arch. 2008, 453, 57-67. [CrossRef] [PubMed]

83. Silva, S.; Perez, D.; Nishimoto, I.; Alves, F.; Pinto, C.; Kowalski, L.; Graner, E. Fatty acid synthase expression in squamous cell carcinoma of the tongue: Clinicopathological findings. Oral Dis. 2008, 14, 376-382. [CrossRef]

84. Almeida, L.Y.D.; Moreira, F.D.S.; Santos, G.A.S.D.; Cuadra Zelaya, F.J.M.; Ortiz, C.A.; Agostini, M.; Mariano, F.S.; Bastos, D.C.; Daher, U.R.N.; Kowalski, L.P.; et al. FASN inhibition sensitizes metastatic OSCC cells to cisplatin and paclitaxel by downregulating cyclin B1. Oral. Dis. 2021. [CrossRef]

85. de Aquino, I.G.; Bastos, D.C.; Cuadra-Zelaya, F.J.M.; Teixeira, I.F.; Salo, T.; Della Coletta, R.; Graner, E. Anticancer properties of the fatty acid synthase inhibitor TVB-3166 on oral squamous cell carcinoma cell lines. Arch. Oral Biol. 2020, 113, 104707. [CrossRef]

86. Wisniewski, D.J.; Ma, T.; Schneider, A. Nicotine induces oral dysplastic keratinocyte migration via fatty acid syn-thase-dependent epidermal growth factor receptor activation. Exp. Cell Res. 2018, 370, 343-352. [CrossRef]

87. Hilvo, M.; Denkert, C.; Lehtinen, L.; Müller, B.; Brockmöller, S.; Seppänen-Laakso, T.; Budczies, J.; Bucher, E.; Yetukuri, L.; Castillo, S.; et al. Novel Theranostic Opportunities Offered by Characterization of Altered Membrane Lipid Metabolism in Breast Cancer Progression. Cancer Res. 2011, 71, 3236-3245. [CrossRef]

88. Dickinson, A.; Saraswat, M.; Joenväärä, S.; Agarwal, R.; Jyllikoski, D.; Wilkman, T.; Mäkitie, A.; Silén, S. Mass spectrometry-based lipidomics of oral squamous cell carcinoma tissue reveals aberrant cholesterol and glycerophospholipid metabolism-A Pilot study. Transl. Oncol. 2020, 13, 100807. [CrossRef]

89. Gumus, R.; Capik, O.; Gundogdu, B.; Tatar, A.; Altinkaynak, K.; Ozdemir Tozlu, O.; Karatas, O.F. Low vitamin D and high cholesterol facilitate oral carcinogenesis in 4NQO-induced rat models via regu-lating glycolysis. Oral Dis. 2021. [CrossRef]

90. Jayakar, S.K.; Loudig, O.; Brandwein-Gensler, M.; Kim, R.S.; Ow, T.J.; Ustun, B.; Harris, T.M.; Prystowsky, M.B.; Childs, G.; Segall, J.E.; et al. Apolipoprotein E Promotes Invasion in Oral Squamous Cell Carcinoma. Am. J. Pathol. 2017, 187, 2259-2272. [CrossRef] 
91. Lai, Y.H.; Liu, H.; Chiang, W.F.; Chen, T.W.; Chu, L.J.; Yu, J.S.; Chen, S.J.; Chen, H.C.; Tan, B.C.M. MiR-31-5p-ACOX1 Axis Enhances Tumorigenic Fitness in Oral Squamous Cell Carcinoma Via the Promi-gratory Prostaglandin E2. Theranostics 2018, 8, 486-504. [CrossRef] [PubMed]

92. Husvik, C.; Khuu, C.; Bryne, M.; Halstensen, T.S. PGE2 Production in Oral Cancer Cell Lines is COX-2-dependent. J. Dent. Res. 2009, 88, 164-169. [CrossRef]

93. Tang, D.-W.; Lin, S.-C.; Chang, K.-W.; Chi, C.-W.; Chang, C.-S.; Liu, T.-Y. Elevated expression of cyclooxygenase (COX)-2 in oral squamous cell carcinoma-evidence for COX-2 induction by areca quid ingredients in oral keratinocytes. J. Oral Pathol. Med. 2003, 32, 522-529. [CrossRef]

94. Nystrom, M.L.; McCulloch, D.; Weinreb, P.H.; Violette, S.M.; Speight, P.M.; Marshall, J.F.; Hart, I.R.; Thomas, G.J. Cyclooxygenase2 inhibition suppresses alphavbeta6 integrin-dependent oral squamous carcinoma invasion. Cancer Res. 2006, 66, 10833-10842. [CrossRef] [PubMed]

95. Butler, L.M.; Perone, Y.; Dehairs, J.; Lupien, L.E.; de Laat, V.; Talebi, A.; Loda, M.; Kinlaw, W.B.; Swinnen, J.V. Lipids and cancer: Emerging roles in pathogenesis, diagnosis and therapeutic intervention. Adv. Drug Deliv. Rev. 2020, 159, 245-293. [CrossRef] [PubMed]

96. Dawes, C.; Pedersen, A.M.L.; Villa, A.; Ekström, J.; Proctor, G.B.; Vissink, A.; Aframian, D.; McGowan, R.; Aliko, A.; Narayana, N.; et al. The functions of human saliva: A review sponsored by the World Workshop on Oral Medicine VI. Arch. Oral Biol. 2015, 60, 863-874. [CrossRef]

97. Kaczor-Urbanowicz, K.E.; Wei, F.; Rao, S.L.; Kim, J.; Shin, H.; Cheng, J.; Tu, M.; Wong, D.T.; Kim, Y. Clinical validity of saliva and novel technology for cancer detection. Biochim. Biophys Acta. Rev. Cancer 2019, 1872, 49-59. [CrossRef]

98. Wang, Q.; Gao, P.; Wang, X.; Duan, Y. Investigation and identification of potential biomarkers in human saliva for the early diagnosis of oral squamous cell carcinoma. Clin. Chim. Acta 2014, 427, 79-85. [CrossRef]

99. Sugimoto, M.; Wong, D.T.; Hirayama, A.; Soga, T.; Tomita, M. Capillary electrophoresis mass spectrometry-based saliva metabolomics identified oral, breast and pancreatic cancer-specific profiles. Metabolomics 2009, 6, 78-95. [CrossRef]

100. Ohshima, M.; Sugahara, K.; Kasahara, K.; Katakura, A. Metabolomic analysis of the saliva of Japanese patients with oral squamous cell carcinoma. Oncol. Rep. 2017, 37, 2727-2734. [CrossRef]

101. Ishikawa, S.; Sugimoto, M.; Kitabatake, K.; Sugano, A.; Nakamura, M.; Kaneko, M.; Ota, S.; Hiwatari, K.; Enomoto, A.; Soga, T.; et al. Identification of salivary metabolomic biomarkers for oral cancer screening. Sci. Rep. 2016, 6, 31520. [CrossRef]

102. Wang, Q.; Gao, P.; Wang, X.; Duan, Y. The early diagnosis and monitoring of squamous cell carcinoma via saliva metabolomics Sci. Rep. 2014, 4, 6802. [CrossRef] [PubMed]

103. Song, X.; Yang, X.; Narayanan, R.; Shankar, V.; Ethiraj, S.; Wang, X.; Duan, N.; Ni, Y.-H.; Hu, Q.; Zare, R.N. Oral squamous cell carcinoma diagnosed from saliva metabolic profiling. Proc. Natl. Acad. Sci. USA 2020, 117, 16167-16173. [CrossRef]

104. Sridharan, G.; Ramani, P.; Patankar, S.; Vijayaraghavan, R. Evaluation of salivary metabolomics in oral leukoplakia and oral squamous cell carcinoma. J. Oral Pathol. Med. 2019, 48, 299-306. [CrossRef]

105. Yang, X.-H.; Jing, Y.; Wang, S.; Ding, F.; Zhang, X.-X.; Chen, S.; Zhang, L.; Hu, Q.-G.; Ni, Y.-H. Integrated Non-targeted and Targeted Metabolomics Uncovers Amino Acid Markers of Oral Squamous Cell Carcinoma. Front. Oncol. 2020, 10, 426. [CrossRef]

106. Gupta, A.; Gupta, S.; Mahdi, A.A. 1H NMR-derived serum metabolomics of leukoplakia and squamous cell carcinoma. Clin. Chim. Acta 2015, 441, 47-55. [CrossRef] [PubMed]

107. de Sá Alves, M.; de Sá Rodrigues, N.; Bandeira, C.M.; Chagas, J.F.S.; Pascoal, M.B.N.; Nepomuceno, G.L.J.T.; da Silva Martinho, H.; Alves, M.G.O.; Mendes, M.A.; Dias, M. Identification of Possible Salivary Metabolic Biomarkers and Altered Metabolic Pathways in South American Patients Diagnosed with Oral Squamous Cell Carcinoma. Metabolites 2021, 11, 650. [CrossRef]

108. Wei, J.; Xie, G.; Zhou, Z.; Shi, P.; Qiu, Y.; Zheng, X.; Chen, T.; Su, M.; Zhao, A.; Jia, W. Salivary metabolite signatures of oral cancer and leukoplakia. Int. J. Cancer 2010, 129, 2207-2217. [CrossRef]

109. Sridharan, G.; Ramani, P.; Patankar, S. Serum metabolomics in oral leukoplakia and oral squamous cell carcinoma. J. Cancer Res. Ther. 2017, 13, 556-561. [CrossRef] [PubMed]

110. Yang, X.; Song, X.; Yang, X.; Han, W.; Fu, Y.; Wang, S.; Zhang, X.; Sun, G.; Lu, Y.; Wang, Z.; et al. Big cohort metabolomic profiling of serum for oral squamous cell carcinoma screening and diagnosis. Nat. Sci. 2022, 2, e20210071. [CrossRef]

111. Acharya, S.; Rai, P.; Hallikeri, K.; Anehosur, V.; Kale, J. Serum lipid profile in oral squamous cell carcinoma: Alterations and association with some clinicopatho-logical parameters and tobacco use. Int. J. Oral Maxillofac. Surg. 2016, 45, 713-720. [CrossRef]

112. Ishikawa, S.; Sugimoto, M.; Edamatsu, K.; Sugano, A.; Kitabatake, K.; Iino, M. Discrimination of oral squamous cell carcinoma from oral lichen planus by salivary metabolomics. Oral Dis. 2019, 26, 35-42. [CrossRef]

113. Voelxen, N.F.; Blatt, S.; Knopf, P.; Henkel, M.; Appelhans, C.; Righesso, L.A.R.; Pabst, A.; Goldschmitt, J.; Walenta, S.; Neff, A.; et al. Comparative metabolic analysis in head and neck cancer and the normal gingiva. Clin. Oral Investig. 2017, 22, 1033-1043. [CrossRef] [PubMed]

114. Yang, X.-H.; Zhang, X.-X.; Jing, Y.; Ding, L.; Fu, Y.; Wang, S.; Hu, S.-Q.; Zhang, L.; Huang, X.-F.; Ni, Y.-H.; et al. Amino acids signatures of distance-related surgical margins of oral squamous cell carcinoma. EBioMedicine 2019, 48, 81-91. [CrossRef]

115. Tsai, C.-K.; Lin, C.-Y.; Kang, C.-J.; Liao, C.-T.; Wang, W.-L.; Chiang, M.-H.; Yen, T.-C.; Lin, G. Nuclear Magnetic Resonance Metabolomics Biomarkers for Identifying High Risk Patients with Extranodal Extension in Oral Squamous Cell Carcinoma. J. Clin. Med. 2020, 9, 951. [CrossRef] 
116. Hsu, C.-W.; Chen, Y.-T.; Hsieh, Y.-J.; Chang, K.-P.; Hsueh, P.-C.; Chen, T.; Yu, J.-S.; Chang, Y.-S.; Li, L.; Wu, C.-C. Integrated analyses utilizing metabolomics and transcriptomics reveal perturbation of the polyamine pathway in oral cavity squamous cell carcinoma. Anal. Chim. Acta 2019, 1050, 113-122. [CrossRef]

117. Askari, M.; Darabi, M.; Mahmudabadi, R.Z.; Oboodiat, M.; Fayezi, S.; Hosseini, Z.M.; Pirzadeh, A. Tissue fatty acid composition and secretory phospholipase-A2 activity in oral squamous cell carcinoma. Clin. Transl. Oncol. 2014, 17, 378-383. [CrossRef]

118. Xie, G.X.; Chen, T.L.; Qiu, Y.P.; Shi, P.; Zheng, X.J.; Su, M.M.; Zhao, A.H.; Zhou, Z.T.; Jia, W. Urine metabolite profiling offers potential early diagnosis of oral cancer. Metabolomics 2012, 8, 220-231. [CrossRef]

119. Yongkui, L.; Jian, L.; Wanghan; Jingui, L. 18FDG-PET/CT for the detection of regional nodal metastasis in patients with primary head and neck cancer before treatment: A meta-analysis. Surg. Oncol. 2013, 22, e11-e16. [CrossRef]

120. Lonneux, M.; Hamoir, M.; Reychler, H.; Maingon, P.; Duvillard, C.; Calais, G.; Bridji, B.; Digue, L.; Toubeau, M.; Grégoire, V. Positron Emission Tomography With [18F] Fluorodeoxyglucose Improves Staging and Patient Management in Patients With Head and Neck Squamous Cell Carcinoma: A Multicenter Prospective Study. J. Clin. Oncol. 2010, 28, 1190-1195. [CrossRef]

121. Gao, S.; Li, S.; Yang, X.; Tang, Q. 18FDG PET-CT for distant metastases in patients with recurrent head and neck cancer after definitive treatment. A meta-analysis. Oral Oncol. 2014, 50, 163-167. [CrossRef] [PubMed]

122. Guduguntla, P.V.; Guttikonda, R. Estimation of serum pyruvic acid levels in oral squamous cell carcinoma. J. Oral Maxillofac. Pathol. 2020, 24, 585.

123. Zuo, L.; Chen, Z.; Chen, L.; Kang, J.; Shi, Y.; Liu, L.; Zhang, S.; Jia, Q.; Huang, Y.; Sun, Z. Integrative Analysis of Metabolomics and Transcriptomics Data Identifies Prognostic Biomarkers Associated With Oral Squamous Cell Carcinoma. Front. Oncol. 2021, 11, 750794. [CrossRef]

124. Ye, G.; Liu, Y.; Yin, P.; Zeng, Z.; Huang, Q.; Kong, H.; Lu, X.; Zhong, L.; Zhang, Z.; Xu, G. Study of Induction Chemotherapy Efficacy in Oral Squamous Cell Carcinoma Using Pseudotargeted Metabolomics. J. Proteome Res. 2014, 13, 1994-2004. [CrossRef]

125. Ruparel, S.; Bendele, M.; Wallace, A.; Green, D. Released Lipids Regulate Transient Receptor Potential Channel (TRP)-Dependent Oral Cancer Pain. Mol. Pain 2015, 11, 30. [CrossRef]

126. Mignion, L.; Acciardo, S.; Gourgue, F.; Joudiou, N.; Caignet, X.; Goebbels, R.-M.; Corbet, C.; Feron, O.; Bouzin, C.; Cani, P.D.; et al Metabolic Imaging Using Hyperpolarized Pyruvate-Lactate Exchange Assesses Response or Resistance to the EGFR Inhibitor Cetuximab in Patient-Derived HNSCC Xenografts. Clin. Cancer Res. 2019, 26, 1932-1943. [CrossRef]

127. Shin, J.M.; Kamarajan, P.; Fenno, J.C.; Rickard, A.H.; Kapila, Y.L. Metabolomics of Head and Neck Cancer: A Mini-Review. Front. Physiol. 2016, 7, 526. [CrossRef]

128. Balog, J.; Sasi-Szabó, L.; Kinross, J.; Lewis, M.R.; Muirhead, L.J.; Veselkov, K.; Mirnezami, R.; Dezső, B.; Damjanovich, L.; Darzi, A.; et al. Intraoperative Tissue Identification Using Rapid Evaporative Ionization Mass Spectrometry. Sci. Transl. Med. 2013, 5, 194ra93. [CrossRef]

129. Uchiyama, Y.; Hayasaka, T.; Masaki, N.; Watanabe, Y.; Masumoto, K.; Nagata, T.; Katou, F.; Setou, M. Imaging mass spectrometry distinguished the cancer and stromal regions of oral squamous cell carci-noma by visualizing phosphatidylcholine (16:0/16:1) and phosphatidylcholine (18:1/20:4). Anal. Bioanal. Chem. 2014, 406, 1307-1316. [CrossRef]

130. Yang, X.; Song, X.; Zhang, X.; Shankar, V.; Wang, S.; Yang, Y.; Chen, S.; Zhang, L.; Ni, Y.; Zare, R.N.; et al. In situ DESI-MSI lipidomic profiles of mucosal margin of oral squamous cell carcinoma. EBioMedicine 2021, 70, 103529. [CrossRef]

131. Eberlin, L.S.; Tibshirani, R.J.; Zhang, J.; Longacre, T.A.; Berry, G.J.; Bingham, D.B.; Norton, J.A.; Zare, R.N.; Poultsides, G.A Molecular assessment of surgical-resection margins of gastric cancer by mass-spectrometric imaging. Proc. Natl. Acad. Sci. USA 2014, 111, 2436-2441. [CrossRef] [PubMed]

132. Kerian, K.S.; Jarmusch, A.K.; Pirro, V.; Koch, M.O.; Masterson, T.A.; Cheng, L.; Cooks, R.G. Differentiation of prostate cancer from normal tissue in radical prostatectomy specimens by desorption electrospray ionization and touch spray ionization mass spectrometry. Analyst 2015, 140, 1090-1098. [CrossRef] [PubMed]

133. Calligaris, D.; Caragacianu, D.; Liu, X.; Norton, I.; Thompson, C.J.; Richardson, A.L.; Golshan, M.; Easterling, M.L.; Santagata, S.; Dillon, D.A.; et al. Application of desorption electrospray ionization mass spectrometry imaging in breast cancer margin analysis. Proc. Natl. Acad. Sci. USA 2014, 111, 15184-15189. [CrossRef] [PubMed] 